\title{
Occupational Hazards in Veterinarians: An Updating
}

Silvia Bonini ${ }^{1}$, Alessandra Buonacucina ${ }^{2}$, Luisella Selis ${ }^{1}$, Angelo Peli $^{3}$, Antonio Mutti ${ }^{1}$ and Massimo Corradi ${ }^{1^{*}}$

${ }^{1}$ Department of Clinical and Experimental Medicine, University of Parma, Via Gramsci 14, 43126 Parma, Italy

${ }^{2}$ Centralized Veterinary Service, University of Bologna, Via Tolara di Sopra 50, 40064 Ozzano dell'Emilia (BO), Italy

${ }^{3}$ Department of Veterinary Medical Sciences, University of Bologna, Via Tolara di Sopra 50, 40064 Ozzano dell'Emilia (BO), Italy

*Corresponding author: Massimo Corradi, Department of Clinical and Experimental Medicine, University of Parma, Via Gramsci 14 , 43126 Parma, Italy, Tel: +390521033098; Fax: +390521033099; E-mail: massimo.corradi@unipr.it

Rec date: Mar 14, 2016; Acc date: Apr 11, 2016; Pub date: Apr 13, 2016

Copyright: ( 2016 Bonini S, et al. This is an open-access article distributed under the terms of the Creative Commons Attribution License, which permits unrestricted use, distribution, and reproduction in any medium, provided the original author and source are credited.

\begin{abstract}
Background: The veterinarian is a complex and varied work: risks in veterinary activity show are more typical of manual work than medical profession. Many reviews analyzed occupational risks related to veterinarians, but compared to the past current risks are more different. This review analyzes veterinary profession considering main occupational risk factors, as defined by World Health Organization: physical, chemical, biological or other agents that may cause harm to an exposed person in the workplace and is potentially modifiable.
\end{abstract}

Methods: Publications investigating physical, chemical, biological, cancer and stress risk as well as effects associated with these exposures through veterinary practice were searched in the PubMed and Web of Science database. Publications were judged to be covered in the review when the following inclusion criteria applied:

Articles should be published in the English language;

Articles published after 2000;

Studies reporting some numerical data about exposures and subjects considered;

Studies concerning health effects regarding only veterinarians associated with exposure to animals, not general population.

Results: Compared to the past, when the main risk of occupational disease was represented by zoonosis (in particular mycotic infections, mange, swine erysipelas, anthrax and tuberculosis), current risks are also represented by new entities such as mental and physical stress. However injuries, radiations, chemicals, zoonosis and allergies continue to represent a considerable portion of professional risks.

Conclusions: Zoonosis, injuries and trauma remain the main occupational risk for veterinarians today, but new emerging risks, such as psychological risks are becoming increasingly important for these workers.

Keywords: Veterinarians; Occupational health; Physical; Chemical; Biological and psychological risk

\section{Abbreviations \\ BSE: Bovine Spongiform Encephalopathy; HEV: Hepatitis E Virus; IARC: International Agency for Research on Cancer; Ig: immunoglobulin; LAA: laboratory animal allergens; MRSA: Methicillin-resistant Staphylococcus aureus; MSD: Musculoskeletal disorders; mSv: millisievert; NIOSH: National Institute for Occupational Safety and Health; PPE: Personal protective equipment; spp.: species; WHO: World Health Organization; WRMSD-UEs: Work-Related Musculoskeletal Disorders of Upper Extremities.}

\section{Introduction}

Veterinary medicine is the science that deals with the health and welfare of animals, particularly with regard to the prevention and cure of diseases. Since the health of humans is connected to the health of animals and the environment, veterinarian protects human health by controlling diseases that are transmitted from animals to humans (zoonoses) and ensuring the health check on foodstuffs of animal origin.

The veterinarian job is a complex and varied work and the risk to undergone by to prove it. The risks in veterinary activity show are typical of the medical profession that manual work.

The veterinarians are employed in a large field of activities, ranging from animal health and welfare to food safety and public health [1]:

Companion animal veterinarians, who treat pets and generally work in private clinics;

Equine veterinarians, who work with horses;

Food animal veterinarians, who work with farm animals such as pigs, cattle, sheep, goats, poultry and other food producing animals as 
fish and bees. They spend much of their time at farms and ranches treating illnesses and injuries and testing for and vaccinating against diseases. They also may advise owners or managers about feeding, housing, and general health practices;

Food safety and inspection veterinarians, veterinary public health concerns all aspects of food production chain from controlling transmissible diseases that may impact on human health to slaughter procedures and inspection of carcasses and products until their sale on the stores; in this field they are made to check on animal products from abroad in order to ensure safe food supplies;

Research veterinarians, who work in laboratories, conducting research on human and animal health problems. These veterinarians may perform tests on experimental animals for example to identify the effects of new drug therapies, or they may test new surgical techniques. They may also research how to prevent, control, or eliminate food- and animal-borne illnesses and diseases. Also there are veterinarians who deal with experimental animals, to ensure their health and welfare;

Veterinarians who work in laboratories, they deal with diagnostic procedures with various specializations: pathological anatomy, microbiology, virology, pharmacology, chemistry applied to foods, immunology, etc.

Veterinarians perform different tasks that can be counted among those at risk for health and safety, in particular herds of animals, lairages, slaughter houses, farms larvae, stables, horse stables and meat processing plans, and much different tasks that relate in various ways to the problem (and risks) Bovine Spongiform Encephalopathy (BSE).

Compared to the past, when the main risk of occupational disease was represented by zoonosis (in particular mycotic infections, mange, swine erysipelas, anthrax and tuberculosis), current risks are also represented by new entities such as mental and physical stress [2]. However injuries, radiations, chemicals, zoonosis and allergies continue to represent a considerable portion of professional risks (Figure 1) [2,3].

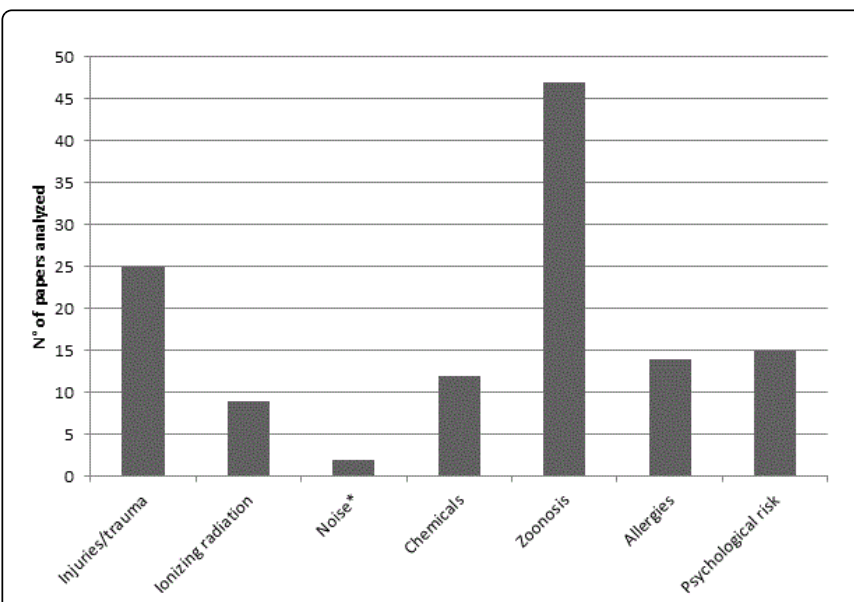

Figure 1: Main type of occupational risks in veterinarians.

\section{Materials and Methods}

Definition of veterinary profession risk factors: This paper analyzes veterinary profession considering main occupational risk factors, as defined by World Health Organization (WHO) [4], physical, chemical, biological or other agents that may cause harm to an exposed person in the workplace and is potentially modifiable.

The main physical risks for veterinary profession are injuries/ trauma/musculoskeletal disorders and ionizing radiations. Chemical risk can result mainly from the use of gaseous anesthetics, drugs (and in particular antineoplastic and antiparasitic agents), detergents and disinfectants. Biological risk is present in all work activities where there is risk of exposure to biological agents that is any organism that may cause infection, allergy or poisoning.

Literature search: Publications investigating physical, chemical, biological, cancer and stress risk as well as effects associated with these exposures through veterinary practice were searched in the PubMed and Web of Science databases. The following search terms were utilized: "occupational exposure", "physical risk", "chemical risk", and "biological risk", "stress", linked with the word "veterinary" or "animal". Publications were judged to be covered in the review when the following inclusion criteria applied:

Articles should be published in the English language;

Articles published after 2000;

Studies reporting some numerical data about exposures and subjects considered;

Studies concerning health effects regarding only veterinarians associated with exposure to animals, not general population.

The process of study selection is shown in Figure 2.

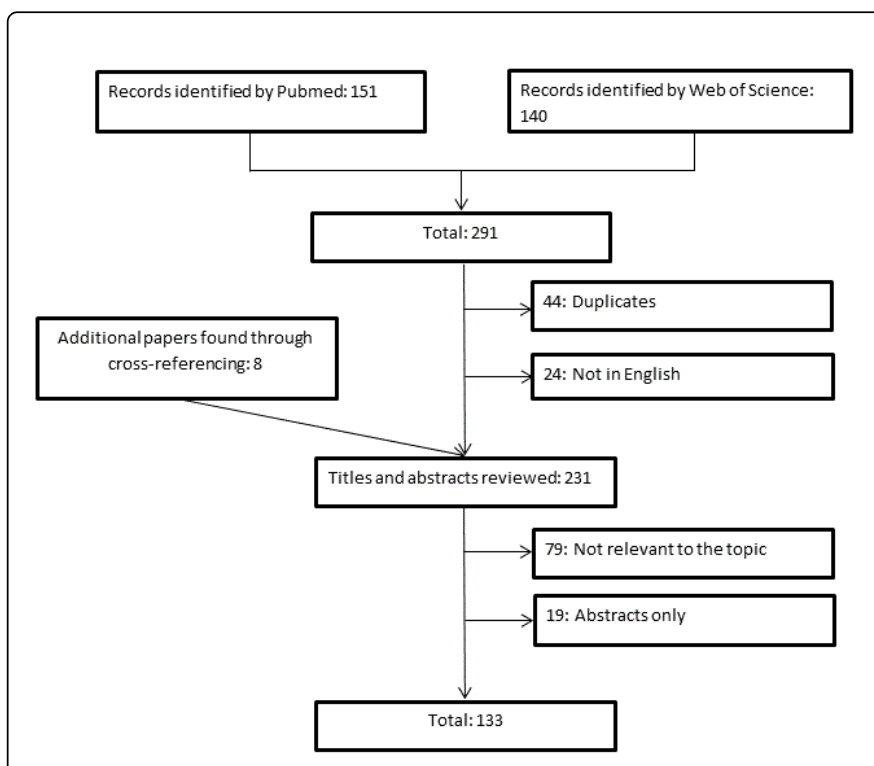

Figure 2: Flow diagram for literature search process. Flow diagram for literature search process in Pubmed and Web of Science databases using following keywords: (veterinary OR vets OR animal) AND (occupational exposure OR exposure OR physical risk OR chemical risk OR biological risk OR stress).

\section{Results}

Physical risk data in veterinary medicine were reported in Table 1: most of chronic or significant injuries and trauma were due to contact with large animals [5-15], in particular horses and cows. The injuries 
Citation: Bonini S, Buonacucina A, Selis L, Peli A, Mutti A, et al. (2016) Occupational Hazards in Veterinarians: An Updating. J Veterinar Sci

Page 3 of 12

most frequently reported were bites [2,5,6,9,10,15-17] scratches [5,9,10,16-18], hits [2,6-10,19] and needle sticks, in particular in zoo vets $[2,9,20-22]$, while the main trauma were associated to chronic work-related musculoskeletal problems and resulted from lifting animals or working in improper postures [11,12,15,16,23-25].

\begin{tabular}{|c|c|c|}
\hline Reference & Title & Type of risk \\
\hline Jeyaretnam and Jones [2] & Physical, chemical and biological hazards in veterinary practice. & Injuries \\
\hline Nienhaus et al. [5] & Work-related accidents and occupational diseases in veterinarians and their staff. & Injuries \\
\hline Lucas et al. [6] & Significant injuries in Australian veterinarians and use of safety precautions. & Injuries \\
\hline Lucas et al. [7] & Injuries to Australian veterinarians working with horses. & Injuries \\
\hline N/A [8] & Survey reveals high risk of injury to equine veterinarians. & Injuries \\
\hline Epp and Waldner [9] & Occupational health hazards in veterinary medicine: Physical, psycological, and chemical hazards. & Injuries, radiations \\
\hline Berry et al. [10] & Cumulative trauma disorders among California veterinarians. & Injuries, trauma \\
\hline Kozak et al. [11] & $\begin{array}{l}\text { Self-Reported Muskuloskeletal Disorders of the Distal Upper Extremities and the Neck in German } \\
\text { Veterinarians: A Cross-Sectional Study. }\end{array}$ & Trauma \\
\hline Reijula et al. [12] & Work environment and occupational health of Finnish veterinarians. & Injuries, trauma, radiations \\
\hline Cattel et al. [13] & $\begin{array}{l}\text { Rectal palpation associated cumulative trauma disorders and acute traumatic injury affecting bovine } \\
\text { practitioners. }\end{array}$ & Injuries, trauma \\
\hline Scuffham et al. [14] & Prevalence and risk factors associated with musculoskeletal discomfort in New Zealand veterinarians. & Trauma \\
\hline Fritschi et al. [15] & Injury in Australian veterinarians. & Injuries, trauma \\
\hline Jeyaretnam et al. [16] & Disease and injury among veterinarians. & Injuries \\
\hline Nigam and Srivastav [17] & Assessing occupational hazards among Indian wildlife health professionals. & Injuries, trauma \\
\hline Nordgren et al. [18] & Evaluation of factors associated with work-related injuries to veterinary technicians certified in Minnesota. & Injuries \\
\hline Lucas et al. [19] & Serious injuries to Australian veterinarians working with cattle. & Injuries \\
\hline Leggat et al. [20] & Exposure rate of needlestick and sharps injuries among Australian veterinarians. & Injuries \\
\hline Weese and Faires [21] & A survey of needle handing practices and needlestick injuries in veterinary technicians. & Injuries \\
\hline Fowler et al. [22] & Survey of occupational hazards in Minnesota veterinary practices in 2012. & Injuries \\
\hline Macdonald and Scott [23] & Scanning through the pain: ergonomic considerations for performing echocardiography of animals. & Trauma \\
\hline Smith et al. [24] & Muskuloskeletal disorders and psychosocial risk factors among veterinarians in Queensland, Australia. & Trauma \\
\hline Scuffham et al. [25] & Tasks considered by veterinarians to cause them musculoskeletal discomfort, and suggested solutions. & Trauma \\
\hline O’Sullivan and Curran [26] & It shouldn't appear to a vet. Occupational injuries in veterinary practitioners working in Ireland. & Trauma \\
\hline Kabuusu et al. [27] & $\begin{array}{l}\text { Prevalence and pattern of self-reported animal-related injury among veterinarians in metropolitan } \\
\text { Kampala. }\end{array}$ & Injuries \\
\hline Wilkins et al. [28] & Veterinarian injuries associated with bovine TB testing livestock in Michigan, 2001. & Injuries \\
\hline Shirangi et al. [3] & Birth defects in offspring of female veterinarians. & Radiations \\
\hline Hall et al. [29] & $\begin{array}{l}\text { Occupational exposures to antineoplastic drugs and ionizing radiation in Canadian veterinary settings: } \\
\text { findings from a national surveillance project. }\end{array}$ & Radiations \\
\hline Shirangi et al. [30] & Maternal occupational exposures and risk of spontaneous abortion in veterinary practite. & Radiations \\
\hline Shirangi et al. [31] & Prevalence of occupational exposures and protective practices in Australian female veterinarians. & Radiations \\
\hline Gatherer et al. [32] & $\begin{array}{l}\text { Exposure of veterinary personnel to ionising radiation during bone scanning of horses by nuclear } \\
\text { scintigraphy with } 99 \text { mtechnetium methylene diphosphonate. }\end{array}$ & Radiations \\
\hline Fritschi [33] & Cancer in veterinarians. & Radiations \\
\hline
\end{tabular}



animals.

Table 1: Papers and relative type of risk about physical agents.

In the studies we found, authors reported an incidence of injuries/ trauma ranging from $49 \%$ to $93 \%[15,20,21,26,27]$.

The most affected parts of the body were upper limb $[2,5,6,10,11,19,23,24,27,28]$, lower limb $[2,8,28]$, head $[2,5,6,8]$, lower back $[10,15,24-26]$ and neck $[10,11,24,25]$. Some authors reported also bone fractures $[2,5,6,7,17]$, which were more frequent when large animals are involved.

Another kind of physical exposure regards radiations; we found 9 studies [3,9,12,29-34] about this risk (Table 1): the majority of the exposures were below the annual limit of $20 \mathrm{mSv} /$ year recommended by International Commission on Radiological Protection [35], except for one study [9]. Some authors reported an increased risk of spontaneous abortion for pregnant medical staff [3,30,31]. In particular dose received by the assistant is on average 6 times higher than the dose received by the veterinarian, and sometimes the received dose is comparable with the recommended limit [34].
Noise is a well-known physical risk factor for several occupational activities, but in veterinary facilities do not normally exist situations or machines that subjecting operators to noises that exceed those permitted.

Hearing loss has not been widely reported in the veterinarians profession: we found only 2 studies published before $2000[9,36]$, but also in these cases there was a small percentage of vets denounced hearing loss.

Chemical risk represents another important risk factor for vets (Figure 1 and Table 2): the majority of exposures regards anesthetics gases $[9,12,16,31,33,37,38]$, in particular for vets who deal with small and mixed animals, and pesticides $[3,9,31,33,39]$. We found a study describing an increased risk of exposure to P.M. in pig-fattening house [40].

\begin{tabular}{|c|c|c|}
\hline Reference & Title & Type of risk \\
\hline Epp and Waldner [9] & Occupational health hazards in veterinary medicine: Physical, psycological, and chemical hazards. & Anesthetics, pesticides, drugs \\
\hline Reijula et al. [12] & Work environment and occupational health of Finnish veterinarians. & Anesthetics, \\
\hline Jeyaretnam et al. [16] & Disease and injury among veterinarians. & Anesthetics, \\
\hline Shirangi et al. [31] & Prevalence of occupational exposures and protective practices in Australian female veterinarians. & Anesthetics, \\
\hline Fritschi [33] & Cancer in veterinarians. & Anesthetics, pesticides \\
\hline Allweiler and Kogan [37] & $\begin{array}{l}\text { Inhalation anesthetics and the reproductive risk associated with occupational exposure among women } \\
\text { working in veterinary anesthesia. }\end{array}$ & Anesthetics \\
\hline Shirangi et al. [38] & $\begin{array}{l}\text { Association of unscaveged anesthetic gases and long working hours with preterm delivery in female } \\
\text { veterinarins. }\end{array}$ & Anesthetics \\
\hline Shirangi et al. [3] & Birth defects in offspring of female veterinarians. & Pesticides \\
\hline Fritschi et al. [39] & Trends in exposure of veterinarians to physical and chemical hazards and use of protection practices. & Pesticides \\
\hline Ransbeeck et al. [40] & $\begin{array}{l}\text { Exposure levels of farmers and veterinarians to particulate matter and gases during operation tasks in } \\
\text { pig-fattening houses. }\end{array}$ & Particulate matter \\
\hline
\end{tabular}

Table 2: Papers and relative type of risk about chemicals.

Some authors report an increased risk for birth defects when using cytotoxic drugs and/or anesthetic gases $[16,30,38,41]$, even if this result is not shared by other studies [37]. Nienhaus et al. describe 2 cases of encephalopathy due to solvent [5].

There are few publications on quantitative exposure to pesticides in the veterinary profession, and they are all published before 2000 .

In Figure 1 we summarized published paper we found about biological risks in veterinary medicine.

Little is known about the prevalence, diagnosis and treatment of zoonotic disease among veterinarians: in our review we found an incidence of zoonosis ranging from $16.6 \%$ to $65.7 \%$ [9,42-45].
The main zoonotic agents we found in our review are reported in Table 3 .

\begin{tabular}{|l|l|l|}
\hline Agent & $\begin{array}{l}\text { No of } \\
\text { studies }\end{array}$ & References \\
\hline H1N1 & 3 & $\begin{array}{l}\text { Myers et al. [60] } \\
\text { Myers et al. [70] } \\
\text { Weller et al. [74] }\end{array}$ \\
\hline Bacillus anthracis & 2 & $\begin{array}{l}\text { Epp et al. [9] } \\
\text { Molineri et al. [42] }\end{array}$ \\
\hline Bartonella spp & 5 & Epp and Waldner [9] \\
\hline
\end{tabular}


Citation: Bonini S, Buonacucina A, Selis L, Peli A, Mutti A, et al. (2016) Occupational Hazards in Veterinarians: An Updating. J Veterinar Sci

Page 5 of 12

\begin{tabular}{|c|c|c|}
\hline & & $\begin{array}{l}\text { Sayin-kutlu et al. [51] } \\
\text { Lantos et al. [121] } \\
\text { Maggi et al. [122] } \\
\text { Lin et al. [123] }\end{array}$ \\
\hline Blastomyces dermatitidis & 1 & Epp et al. [9] \\
\hline Borrelia burgdoferi & 1 & Nienhaus et al. [5] \\
\hline Bovine norovirus & 1 & Widdowson et al. [75] \\
\hline Brucella spp. & 9 & $\begin{array}{l}\text { Nienhaus et al. [5] } \\
\text { Epp and Waldner [9] } \\
\text { Molineri et al. [42] } \\
\text { Ergönül et al. [124] } \\
\text { Reid [125] } \\
\text { Kutlu et al. [126] } \\
\text { Shalmali et al. [127] } \\
\text { Van den Brom et al. } \\
\text { [128] } \\
\text { Thakur and Thapliyal } \\
\text { [129] }\end{array}$ \\
\hline Campylobacter & 1 & Epp and Waldner [9] \\
\hline Chlamydophilapsittaci & 2 & $\begin{array}{l}\text { Nienhaus et al. [5] } \\
\text { Raso et al. [141] }\end{array}$ \\
\hline Coxiellaburnetii & 9 & $\begin{array}{l}\text { Vest and Clark [132] } \\
\text { Abe et al. [133] } \\
\text { Dorko et al. [134] } \\
\text { De Rooij et al. [135] } \\
\text { Bernard et al. [50] } \\
\text { Ergönül et al. [124] } \\
\text { Bacci et al. [78] } \\
\text { Chang et al. [136] } \\
\text { Wielders et al. [137] } \\
\text { Fenga et al. [138] } \\
\text { Whytney et al. [88] }\end{array}$ \\
\hline Crimean-Congo hemorrhagic fever & 1 & Ergönül et al. [124] \\
\hline Cryptosporidium spp & 1 & Epp and Waldner [9] \\
\hline Encephalomyocarditis virus & 1 & $\begin{array}{l}\text { Rivera-Benitez et al. } \\
{[48]}\end{array}$ \\
\hline Feline foamy virus & 1 & Butera et al. [49] \\
\hline Feline immunodeficiency virus & 1 & Butera et al. [49] \\
\hline Giardia spp & 1 & Epp and Waldner [9] \\
\hline Helicobacter suis & 1 & Joosten et al. [72] \\
\hline Hendra virus & 1 & Mendez et al. [58] \\
\hline Hepatitis E & 3 & $\begin{array}{l}\text { Meng et al. [46] } \\
\text { Chaussade et al. [79] } \\
\text { Mendez et al. [58] }\end{array}$ \\
\hline Leptospira spp & 4 & $\begin{array}{l}\text { Rivera-Benitez et al. } \\
\text { [48] } \\
\text { Molineri et al. [42] }\end{array}$ \\
\hline
\end{tabular}

\begin{tabular}{|c|c|c|}
\hline & & $\begin{array}{l}\text { Baer et al. [81] } \\
\text { Sanhueza et al. [86] } \\
\text { Whytney et al. [88] }\end{array}$ \\
\hline Listeria spp & 2 & $\begin{array}{l}\text { Regan et al. [59] } \\
\text { Zelenik et al. [73] }\end{array}$ \\
\hline $\begin{array}{l}\text { Methicillin-resistant Staphylococcus } \\
\text { aureus }\end{array}$ & 15 & $\begin{array}{l}\text { Epp and Waldner [9] } \\
\text { Zemlickova et al. [130] } \\
\text { Schawaber et al. [52] } \\
\text { Jordan et al. [53] } \\
\text { Loeffler et al. [54] } \\
\text { Ishiara et al. [55] } \\
\text { Paul et al. [56] } \\
\text { Huber et al. [57] } \\
\text { Verkade et al. [76] } \\
\text { Moodley et al. [80] } \\
\text { Garcia-Graels et al. [82] } \\
\text { O'Mahony et al. [131] } \\
\text { Burstiner et al. [83] } \\
\text { Rosenkranz et al. [84] } \\
\text { Cuny et al. [85] }\end{array}$ \\
\hline Microsporum spp & 2 & $\begin{array}{l}\text { Epp and Waldner [9] } \\
\text { Molineri et al. [42] }\end{array}$ \\
\hline Mycobacterium tuberculosis & 2 & $\begin{array}{l}\text { Molineri et al. [42] } \\
\text { Cooke et al. [161] }\end{array}$ \\
\hline Novel Canine norovirus & 1 & Mesquita et al. [62] \\
\hline Porcine rubulavirus & 1 & $\begin{array}{l}\text { Rivera-Benitez et al. } \\
\text { [48] }\end{array}$ \\
\hline Rabies virus & 3 & $\begin{array}{l}\text { Jackson and Villarroel } \\
\text { [43] } \\
\text { Epp and Waldner [9] } \\
\text { Molineri et al. [42] }\end{array}$ \\
\hline Toxoplasma gondii & 3 & $\begin{array}{l}\text { Molineri et al. [42] } \\
\text { Shuhaibe et al. [139] } \\
\text { Rahman et al. [140] }\end{array}$ \\
\hline Trichophyton spp & 2 & $\begin{array}{l}\text { Epp and Waldner [9] } \\
\text { Molineri et al. [42] }\end{array}$ \\
\hline West Nile Virus & 1 & Epp and Waldner [9] \\
\hline
\end{tabular}

Table 3: Zoonotic agents we found in our review.

The most reported animals which can cause zoonosis in literature are primarily food animals $[9,43,46-53]$ in particular swine and cattle, and companion animals in particular dogs, cats and, to a lesser extent, birds. Equine are mentioned in a few studies [54-88].

The contact and the manipulation of animals can determine the appearance of numerous clinical forms allergic. The prevalence of allergic diseases increased with the length of occupational exposure and female veterinarians in practice were more likely to develop allergies than were male veterinarians [5,9]; in our review we found an incidence of zoonosis ranging from $5 \%$ to $63 \%[9,12,36,63,64,68,89]$, 
with the highest incidence reported for respiratory symptoms $(5,12,63-65,90,91)$. Rhinitis was the most frequent one, followed by cough/chest tightness, wheezing and airways obstruction. 6 studies reported skin problems: dermatosis was the most frequent disease $[12,63,64,66,89,92]$.

The most common agents which can cause symptoms are animalrelated products: body fluids, hair, dander, latex and chemicals $[9,63,64,66,68,90,93]$.

Occupational health problems arising from mental or physical fatigue have rarely been assessed. Veterinarians, especially practice principals, have an enormous responsibility in managing a veterinary practice. In Figure 1 are represented studies concerning stress we found in our review.

In the studies we found authors reported a stress incidence ranging from $37 \%$ to $73 \%[9,12,94]$. The main causes reported were long hours working by day [95-100], client expectations [97-100] and physical demand $[96,98-100]$.

Women and younger vets seem to be exposed to higher stress levels [12,95,97-102].

Some stress is necessary for achieving one's best performance, but poorly managed stress can result in burnout, substance abuse, depression, anxiety, relationship distress, a negative work-home life environment, and even suicide [98,99,103-106].

\section{Discussion}

In this paper we analyzed veterinary profession considering main occupational risk factors: physical, chemical and biological, next to an emerging risk factor: psychological risk.

Many studies on veterinary profession have demonstrated that veterinary work is physically demanding and poses an elevated risk of severe injuries and/or trauma: from the analysis of literature we did, we can affirm that physical risk (which includes injuries/trauma, radiation and noise) remain one of the main risk factors for veterinary activities.

Trauma include bites, scratches and injuries caused by animals to handling errors and containment of the animals themselves; injuries from sharp instruments such as syringes, needles, scalpel blades, nose tongs for cattle, halters, calf pulling equipment, metal cattle chutes and injuries from falls on slippery surfaces. Large animals and cattle was the species most likely to cause injury, predominantly in the upper extremities, but also dog bites, cat bites and scratches and horse kicks resulted particularly dangerous [5]. Sharp instruments are a frequent agent of injuries, but it is unlikely that they cause severe injuries alone: more likely it will be the chemical or biological agents introduced that cause severe problems [16].

In addition to acute injuries, veterinarians suffer from Repetitive Strain injuries or Musculoskeletal disorders (MSD), best known in literature as "Work-Related Musculoskeletal Disorders of Upper Extremities" (WRMSDs-UE), which are inflammatory and degenerative disorders responsible for pain and functional impairment in tendons, muscles, joints, nerves or blood vessels. Static or awkward postures, repetitive or forceful tasks may be risk factors for the development of MSD in the upper extremities and backbone, and it could make worse by pressure of time, work stress, career structure and after hours duties [12,24,107]. Some practitioners, in particular those employed in imaging, work with one or both arms above shoulder level for over one hour daily [23], and this could be an important risk factor for the development of MSD in the upper extremities.

Another kind of physical exposure regards ionizing radiations: it is thought that most practicing veterinarians use radiographic equipment; this occurrence is more frequently in veterinary procedures since the animals must be restrained and therefore the operator could be very close to the source of radiations. Despite this, it seems that veterinarians currently have lower exposures than radiologists and surgeons: the majority of the exposures we found were below the annual limit of $20 \mathrm{mSv} /$ year, except one [9]. There are known risks of skin cancer, thyroid cancer, and leukaemia with exposure to Xrays, but the doses received in veterinary practice are probably insufficient to cause major increases in risk, unless there are problems with the equipment or with radiology procedures.

Noise is a well-known risk factor for several occupational activities, but hearing loss has not been widely reported in the veterinary profession: actually in veterinary facilities do not normally exist situations or machines that subjecting operators to noises that exceed those permitted.

Chemical risk appeared to be less relevant than physical and biological risk, but it could be due to undernotification of claims, which it is not always easy to recognize the causal link: many substances used in veterinary practice may accidentally be split on the skin, inhaled, ingested or injected and can cause hazardous effects, which include mutagenicity, teratogenicity, carcinogenity, acute toxicity, flammability, explosiveness, skin irritation, allergic reactions and lung damage.

Among chemicals, the majority of exposures regards anesthetics gases: dispersion of these chemical compounds in the operating room depends on several factors (conveyance and disposal of gas, the quality and amount of ventilation of the room, taking into account the issue of the gas inhaled by the animal anesthetized through the respiratory tract); although there are no statistical data on their concentration, it is possible to assume, on the basis of known concentrations of the same hospital halls, that an exhibition is not indifferent. Anesthetics are then accused of disorders of the central nervous system and peripheral, liver (especially halothane) and kidney; females were more likely to experience adverse reactions, which included headache, nausea, sleepiness and dizziness [16]. The risk of adverse pregnancy outcome or spontaneous abortion has been analyzed in several studies $[30,38,108-110]$, but, thus far, the results have been inconclusive. Also the evidence of cancerogenicity of volatile anaesthetics was an important risk factor: its role was reviewed by IARC 1987. In the past years some authors reported an increase in lymphohaemopoietic and pancreatic cancer but these were not consistent $[33,111,112]$ and actually we didn't find any recent work about this topic.

Drugs, in particular antineoplastic drugs are a potential problem for the operator private veterinarian, since the chemotherapy is an increasing practice for pets and thus the existence of such risk entails the necessary allocation of appropriate protective equipment (gloves, masks, chemical hood, etc.).

Drugs can also cause allergic contact dermatitis and antibiotics are the most common sensitizers [93]. It has been suggested that prostaglandins could cause adverse respiratory conditions and abortion [2]: in past years Wilkins and Bowman reported a spontaneous abortion after an accidental self -injection of a prostaglandin compound [113]. 
Detergents, disinfectants and pesticides are used directly on animals to control parasites or applied to the area where animals are confined for cleaning and disinfection of premises, equipment and tools for the prevention of infectious and contagious diseases, postoperative and iatrogenic infections. They may present hazards to contact (burns), inhalation (inflammation of the mucous membranes of the respiratory tract and ocular-conjunctival) and special attention should be paid to products that cause toxic, carcinogenic and teratogenic effects.

There are few publications on quantitative exposure to pesticides in the veterinary profession, and they are all published before 2000: some veterinarians had experienced mild symptoms of poisoning, but there was no consistent and progressive depression of blood cholinesterase activities [114]. Handlers who used flea control products were significantly more likely to report symptoms such as skin rash, tearing, unusual tiredness, burning of the eyes and flushing of skin [115]. Some studies in the past demonstrated that use of flea and tick dips could be a risk factor for cancer: Glickman showed that these substances could be a risk factor for bladder cancer in dogs, but the relevance of this to human carcinogenesis is unknown [116], while a case-control study examined the risk of non-Hodgkin's lymphoma with use of lindane: they found a slight significant increase in the risk with ever use of lindane [117].

Biological risk continued to be the main occupational risk for vets: it is present in all work activities where there is risk of exposure to biological agents. Zoonosis and allergic reactions (respiratory symptoms or allergic contact dermatitis) to animal hair, dandruff and feathers proved to be the most frequent cause of all verified occupational diseases in veterinary practice [5]. NIOSH reports that there are approximately two million workers with jobs requiring constant handling of animals [120].

A zoonosis can be defined as "any disease or infection caused by all types of agents (bacteria, parasites, fungi, viruses and unconventional agents) transmissible from vertebrate animals to humans and viceversa" [121]; as for biological risk from zoonoses is difficult to express the extent of damage expected: the consequences of exposure to the most common zoonotic agents may vary from the simple seroconversion to the disease with extremely variable symptomatic manifestations until the onset of irreversible sequelae or death. Damage is conditioned by different parameters such as infectious dose received, pathogenicity of the strain, individual immune status, presence of risk factors such as drug treatments, disease or intercurrent infection, age, physiological state (pregnancy).

Little is known about the prevalence, diagnosis and treatment of zoonotic disease among veterinarians; in our review we found an incidence of zoonosis ranging from $16.6 \%$ to $65.7 \%$ [9,42-45].

Zoonotic agents can be transmitted through various routes: those transmitted via skin contact without breaking the skin include agents such as ringworm [9,42]: actually these agents did not seem to represent the main cause of zoonosis. Diseases requiring a break in the skin's integrity include cat scratch disease (Bartonella henselae), leptospirosis, rabies and brucellosis are frequently reported [5,9,42,43,48,51,81,86,88,120-128]. A third category includes diseases caused by agents that are aerosolized and inhaled, such as $\mathrm{H} 1 \mathrm{~N} 1$, Bacillus anthracis, Brucella spp, MRSA and Q fever (even if the route transmission of this last agent remain unclear): respiratory route remained the main route of zoonosis transmission $[9,42,50,52-57,60,70,74,76,78,80,82-85,88,123,129-137]$. The oral or ingestion route includes a large number of zoonotic agents such as
Cryptosporidia, Campylobacter species (spp), HEV, Toxoplasma $[9,46,58,79,138,139]$. Another possible route is ocular exposure to agents such as Chlamydia [5,141]. Food animals, in particular swine and cattle, and companion animals (dog, cats and birds too) were the main responsible for the transmission of zoonosis: this result could be easily assume because these animals are very common in the population.

During recent decades, the public health risk represented by zoonosis was suggested by the onset of previously unknown human infection diseases that emerged from animal reservoirs such as Ebola virus, West Nile virus, Creutzfeld-Jakob diseases $[9,141]$.

Zoonosis are also suspected to bring about an increased risk of cancer, as suggested by some epidemiological data showing that veterinarians, meat inspectors and slaughterhouse workers experience an increased risk of myelolymphoproliferative disorders attributed to contact with animal oncoviruses, in particular those associated with poultry and cattle farming [142-146]. Exposure to oncogenic viruses, in particular papillomaviruses, could also be an etiologic agent of esophageal cancer in cattle and humans: some studies reported an increased risk of esophageal cancer in veterinarians [135,147].

Fortunately cancer risk in general seems to be declining: in our literature review we didn't find any recent study about this topic. This could be due to a better awareness of occupational risks, in addition to a reduction of carcinogens, in particular physical (radiation) and chemical agents, and to the application of protective measures, both collective and individual.

The contact and the manipulation of animals can also determine the appearance of numerous clinical forms allergic. The prevalence of allergic diseases increased with the length of occupational exposure [16]; female veterinarians in practice appeared to be more likely to develop allergies than were male veterinarians [9].

This occupational disease affects veterinary staff who have daily contact and close to the animals [67], the staff becomes more sensitive to inhaled allergens suspended in the atmosphere or as a result of abrasion, scratches or bites. The majority of the allergens can be defined as bio-aerosol, dust with a heterogeneous composition containing many toxic and immunogenic particles, for instance pathogenic and/or non-pathogenic microorganisms (bacteria, viruses and fungi) and their biological active components (bacterial endotoxin, mycotoxin), plant fragments (pollen) and animal-derived materials (hair, dander and allergens) and these allergens are associated with mammalians, such as cows, horses, cats, dogs, rats and mice $[9,65-67,148]$.

Rats and mice are the animals most commonly used in scientific experimental studies: occupational exposure to these animals often occurs when working with laboratory animals. The prevalence of allergy against rats in laboratory animal's workers ranged from 12-31\% in some recent studies, and for mice ranged from 10-32\% [149,150]. Several epidemiological studies showed a strong association between intensity of exposure to laboratory animal allergens and elevated prevalence of LAA $[151,152]$ : this higher prevalence of allergy against rats and mice, compared to other animal allergens, is probably due to the more frequent use of these animals in experimental studies, and not to lesser ability of other animal allergens to trigger allergy [67].

A substantial number of veterinarians showed sensitivity to latex surgical gloves or powder within the gloves $[9,63,64,66,90]$ : $5-12 \%$ of 
veterinarians interviewed in American studies reported a skin reaction to latex gloves [36].

In the past years contact with biological agents, in particular mycotoxins and bacterial endotoxins, could also result in poisoning. Mycotoxins are toxic substances produced by the metabolism of fungi or molds, which develop, under certain conditions on grass silage, grain and feed business or industrial; the most common agents are Aspergillus, whose aflatoxin is carcinogenic, hepatotoxic, immunosuppressant, Fusarium, whose fumonisin is neurotoxic, carcinogenic, genotoxic and zearalenone is estrogen-like, and Penicillium, whose ochratoxin is nephrotoxic, teratogenic, immunosuppressant and carcinogenic [153]. Contamination can occur on the field or during the later stages of transport, processing and storage.

While the mycete can be considered a pathogen for the plant, ingestion of mycotoxins can cause acute and chronic toxicity in humans and in animals.

Plants most frequently at risk to cause intoxication are peanuts and derivatives, flour and corn germ, corn gluten feed and corn grain; symptoms than can occur are divided in acute and chronic: the former include systemic and respiratory symptoms due to increasing of inflammatory response, while the second include an accelerated lung function decline [154,155]; in our revision of literature we didn't find any recent paper about this topic: notification could be underestimated, especially in poorer countries. It's also probable a real decrement of their incidence thanks to an improvement in information and prevention of this risk.

Occupational health problems arising from mental or physical fatigue have rarely been assessed, but this risk seems to become increasingly important in the last years. Veterinarians, especially practice principals, have an enormous responsibility in managing a veterinary practice; this includes activities such as ordering chemicals and drugs, overseeing the running of the hospital, supervising the business operation, medical and surgical management and generally being involved in community activities such as speaking at local meetings and schools: this combination of work and non-job responsibilities can cause considerable mental stress, burn-out and also an increased risk of suicide.

Sources of stress that create poor wellness in veterinarians include giving bad news, managing adverse events, long hours worked by day, clients expectations, working in teams, and balancing work and home life. But handling ethical dilemmas, in particular regarding euthanasia (especially among veterinarians involved in small animal and equine work $[12,95,96,99,156-158]$, seemed to be the worst stressor. Some stress is necessary for achieving one's best performance, but poorly managed stress can result in burnout, substance abuse, depression, anxiety, relationship distress, abuse of tobacco, alcohol and drugs, a negative work-home life environment, and even suicide, in particular in women and younger vets $[12,94,99,100,101-106,159,160]$.

\section{Conclusions}

The analysis of recent works about veterinarian occupational risks showed some changes compared to the past.

Biological risk (zoonosis) remained the most common risk represented in literature: MRSA, Coxiella burnetii and Brucella spp were the most common infections for vets. Beside this risk, injuries and trauma remained an important risk factor, probably due to intensive working rhythms and pressure of time.

Compared to the past the main change was represented by mental stress and suicide risk arising from mental or physical fatigue, which became increasingly important in the last years.

Ionizing radiation risk is still represented, even if the majority of works we analyzed did not consider it as a risk because doses did not exceed the maximum level permitted.

Chemical risk, in particular anesthetics and drugs remained an important risk for pregnant women, even if results were inconclusive. Also allergic risk was still present in literature: it was related to bioaerosol in particular, but also to drugs, detergents and disinfectant exposure.

Noise risk was not represented in our review: compared to the past it became a marginal risk thanks to PPE and technological improvements.

\section{References}

1. Bureau of Labor Statistics (2015) US Department of Labor, Occupational Outlook Handbook.

2. Jeyaretnam J, Jones H (2000) Physical, chemical and biological hazards in veterinary practice. Aust Vet J 78: 751-758.

3. Shirangi A, Fritschi L, Holman CD, Bower C (2009) Birth defects in offspring of female veterinarians. J Occup Environ Med 51: 525-533.

4. Ezzati M, Lopez AD, Rodges A, Murray CJL (2004) Comparative quantification of health risks. World Health Organization (WHO), Geneva.

5. Nienhaus A, Skudlik C, Seidler A (2005) Work-related accidents and occupational diseases in veterinarians and their staff. Int Arch Occup Environ Health 78: 230-238.

6. Lucas M, Day L, Shirangi A, Fritschi L (2009) Significant injuries in Australian veterinarians and use of safety precautions. Occup Med (Lond) 59: 327-333.

7. Lucas M, Day L, Fritschi L (2009) Injuries to Australian veterinarians working with horses. Vet Rec 164: 207-209.

8. [No authors listed] (2014) Survey reveals high risk of injury to equine vets. Vet Rec 175: 263.

9. Epp T, Waldner C (2012) Occupational health hazards in veterinary medicine: physical, psychological, and chemical hazards. Can Vet J 53: 151-157.

10. Berry SL, Susitaival P, Ahmadi A, Schenker MB (2012) Cumulative trauma disorders among California veterinarians. Am J Ind Med 55: 855-861.

11. Kozak A, Schedlbauer G, Peters C, Nienhaus A (2014) Self-reported musculoskeletal disorders of the distal upper extremities and the neck in German veterinarians: a cross-sectional study. PLoS One 9: e89362.

12. Reijula K, Räsänen $\mathrm{K}$, Hämäläinen $\mathrm{M}$, Juntunen $\mathrm{K}$, Lindbohm ML, et al. (2003) Work environment and occupational health of Finnish veterinarians. Am J Ind Med 44: 46-57.

13. Cattel MB (2000) Rectal palpation associated cumulative trauma disorders and acute traumatic injury affecting bovine practitioners. Bovine Pract 34: 1-5.

14. Scuffham AM, Legg SJ, Firth EC, Stevenson MA (2010) Prevalence and risk factors associated with musculoskeletal discomfort in New Zealand veterinarians. Appl Ergon 41: 444-453.

15. Fritschi L, Day L, Shirangi A, Robertson I, Lucas M, et al. (2006) Injury in Australian veterinarians. Occup Med (Lond) 56: 199-203.

16. Jeyaretnam J, Jones H, Phillips M (2000) Disease and injury among veterinarians. Aust Vet J 78: 625-629.

17. Nigam P, Srivastav A (2011) Assessing occupational hazards among Indian wildlife health professionals. Veterin Arski Arhiv 81: 731-741. 
18. Nordgren LD, Gerberich SG, Alexander BH, Church TR, Bender JB, et al (2014) Evaluation of factors associated with work-related injuries to veterinary technicians certified in Minnesota. J Am Vet Med Assoc 245: 425-433.

19. Lucas M, Day L, Fritschi L (2013) Serious injuries to Australian veterinarians working with cattle. Aust Vet J 91: 57-60.

20. Leggat PA, Smith DR, Speare R (2009) Exposure rate of needlestick and sharps injuries among Australian veterinarians. J Occup Med Toxicol 4: 25.

21. Weese JS, Faires M (2009) A survey of needle handling practices and needlestick injuries in veterinary technicians. Can Vet J 50: 1278-1282.

22. Fowler HN, Holzbauer SM, Smith KE, Scheftel JM (2016) Survey of occupational hazards in Minnesota veterinary practices in 2012. J Am Vet Med Assoc 248: 207-218.

23. Macdonald K, Scott P (2013) Scanning through the pain: ergonomic considerations for performing echocardiography of animals. J Vet Cardiol 15: 57-63.

24. Smith DR, Leggat PA, Speare R (2009) Musculoskeletal disorders and psychosocial risk factors among veterinarians in Queensland, Australia. Aust Vet J 87: 260-265.

25. Scuffham AM, Firth EC, Stevenson MA, Legg SJ (2010) Tasks considered by veterinarians to cause them musculoskeletal discomfort, and suggested solutions. N Z Vet J 58: 37-44.

26. Sullivan KO, Curran N (2008) It shouldn't appear to a vet, Occupational injuries in veterinary practitioners working in Ireland. Ir Vet J 61: 584-587.

27. Kabuusu RM, Keku EO, Kiyini R, McCann TJ (2010) Prevalence and patterns of self-reported animal-related injury among veterinarians in metropolitan Kampala. J Vet Sci 11: 363-365.

28. Wilkins MJ, Bartlett PC, Judge LJ, Erskine RJ, Boulton ML, et al. (2009) Veterinarian injuries associated with bovine TB testing livestock in Michigan, 2001. Prev Vet Med 89: 185-190.

29. Hall L, Davies HW, Demers PA, Nicol AM, Peters CE (2013) Occupational exposures to antineoplastic drugs and ionizing radiation in Canadian veterinary settings: findings from a national surveillance project. Can J Public Health 104: 460-465.

30. Shirangi A, Fritschi L, Holman CD (2008) Maternal occupational exposures and risk of spontaneous abortion in veterinary practice. Occup Environ Med 65: 719-725.

31. Shirangi A, Fritschi L, Holman CD (2007) Prevalence of occupational exposures and protective practices in Australian female veterinarians. Aust Vet J 85: 32-38.

32. Gatherer ME, Faulkner J, Voûte LC (2007) Exposure of veterinary personnel to ionising radiation during bone scanning of horses by nuclear scintigraphy with 99 mtechnetium methylene diphosphonate. Vet Rec 160: 832-835.

33. Fritschi L (2000) Cancer in veterinarians. Occup Environ Med 57: 289-297.

34. Canato GR, Drumond LF, Paschuk SA, Asfora VK, Andrade MEA, et al. (2014) Occupational exposure assessment in procedures of portable digital veterinary radiology for small size animals. Radiat Phys Chem 95: 284-287.

35. [No authors listed] (2007) The 2007 Recommendations of the International Commission on Radiological Protection. ICRP publication 103. Ann ICRP 37: 1-332.

36. Hafer AL, Langley RL, Morrow WEM, Tulis JJ (1996). Occupational hazards reported by swine veterinarians in the United States. J Swine HealthProd 4: 128-141.

37. Allweiler SI, Kogan LR (2013) Inhalation anesthetics and the reproductive risk associated with occupational exposure among women working in veterinary anesthesia. Vet Anaesth Analg 40: 285-289.

38. Shirangi A, Fritschi L, Holman CD (2009) Associations of unscavenged anesthetic gases and long working hours with preterm delivery in female veterinarians. Obstet Gynecol 113: 1008-1017.
39. Fritschi L, Shirangi A, Robertson ID, Day LM (2008) Trends in exposure of veterinarians to physical and chemical hazards and use of protection practices. Int Arch Occup Environ Health 81: 371-378.

40. Van Ransbeeck N, Van Langenhove H, Michiels A, Sonck B, Demeyer P (2014) Exposure levels of farmers and veterinarians to particulate matter and gases during operational tasks in pig-fattening houses. Ann Agric Environ Med 21: 472-478.

41. Shirangi A, Bower C, Holman CD, Preen DB, Bruce N (2014) A study of handling cytotoxic drugs and risk of birth defects in offspring of female veterinarians. Int J Environ Res Public Health 11: 6216-6230.

42. Molineri A, Signorini ML, Pérez L, Tarabla HD (2013) Zoonoses in rural veterinarians in the central region of Argentina. Aust J Rural Health 21: 285-290.

43. Jackson J, Villarroel A (2012) A survey of the risk of zoonoses for veterinarians. Zoonoses Public Health 59: 193-201.

44. Dowd K, Taylor M, Toribio JA, Hooker C, Dhand NK (2013) Zoonotic disease risk perceptions and infection control practices of Australian veterinarians: call for change in work culture. Prev Vet Med 111: 17-24.

45. Gummow B (2003) A survey of zoonotic diseases contracted by South African veterinarians. J S Afr Vet Assoc 74: 72-76.

46. Meng XJ, Wiseman B, Elvinger F, Guenette DK, Toth TE, et al. (2002) Prevalence of antibodies to hepatitis $\mathrm{E}$ virus in veterinarians working with swine and in normal blood donors in the United States and other countries. J Clin Microbiol 40: 117-122.

47. Brito MG, Chamone TL, da Silva FJ, Wada MY, Miranda AB, et al. (2011) Antemortem diagnosis of human rabies in a veterinarian infected when handling a herbivore in Minas Gerais, Brazil. Rev Inst Med Trop Sao Paulo 53: 39-44.

48. Rivera-Benitez JF, Rosas-Estrada K, Pulido-Camarillo E, de la PeñaMoctezuma A, Castillo-Juárez H, et al. (2014) Serological survey of veterinarians to assess the zoonotic potential of three emerging swine diseases in Mexico. Zoonoses Public Health 61: 131-137.

49. Butera ST, Brown J, Callahan ME, Owen SM, Matthews AL, et al. (2000) Survey of veterinary conference attendees for evidence of zoonotic infection by feline retroviruses. J Am Vet Med Assoc 217: 1475-1479.

50. Bernard H, Brockmann SO, Kleinkauf N, Klinc C, Wagner-Wiening C, et al. (2012) High seroprevalence of Coxiella burnetii antibodies in veterinarians associated with cattle obstetrics, Bavaria, 2009. Vector Borne Zoonotic Dis 12: 552-557.

51. Sayin-kutlu S, Ergin C, Kutlu M, Akkaya Y, Akalin S (2012) Bartonella henselae seroprevalence in cattle breeders and veterinarians in the rural areas af Aydin and Denizli, Turkey. Zoonoses Public Health 59: 445-449.

52. Schawaber MJ, Navon-Venezia S, Masarwa S, Tirosh-Levy S, Adler A, et al (2013) Clonal transmission of a rare methicillin-resistant Staphylococcus aureus genotype between horses and staff at a veterinary teaching hospital. Vet Microbiol 162: 907-911.

53. Jordan D, Simon J, Fury S, Moss S, Giffard P, et al. (2011) Carriage of methicillin-resistant Staphylococcus aureus by veterinarians in Australia. Aust Vet J 89: 152-159.

54. Loeffler A, Boag AK, Sung J, Lindsay JA, Guardabassi L, et al (2005) Prevalence of methicillin-resistant Staphilococcus aureus among staff and pets in a small animal referral hospital in the UK. J Antimicrob Chemoter 56: 692-697.

55. Ishihara K, Saito M, Shimokubo N, Muramatsu Y, Maetani S, et al. (2014) Methicillin-resistant Staphylococcus aureus carriage among veterinary staff and dogs in private veterinary clinics in Hokkaido, Japan. Microbiol Immunol 58: 149-154.

56. Paul NC, Moodley A, Ghibaudo G, Guardabassi L (2011) Carriage of methicillin-resistant Staphylococcus pseudointermedius in small animal veterinarians: indirect evidence of zoonotic transmission. Zoonosis Public Health 58: 533-539.

57. Huber H, Koller S, Giezendanner N, Stephan R, Zweifel C (2010) Prevalence and characteristics of methicillin-resistant Staphylococcus aureus in humans in contact with farm animals, in livestock, and in food of animal origin, Switzerland. Euro Surveil 234: 1271-1278. 
58. Mendez D, Buttner P, Speare R (2014) Hendra virus in Queensland, Australia, during the winter of 2011: veterinarians on the path to better management strategies. Prev Vet Med 117: 40-51.

59. Regan EJ, Harrison GA, Butler S, McLauchlin J, Thomas M, et al. (2005) Primary cutaneous listeriosis in a veterinarian. Vet Rec 157: 207.

60. Myers KP, Setterquist SF, Capuano AW, Gray GC (2007) Infection due to 3 avian influenza subtypes in United States veterinarians. Clin Infect Dis 45: 4-9.

61. Barmettler R, Schweighauser A, Bigler S, Grooters AM, Francey T (2011) Assessment of exposure to Leptospira serovars in veterinary staff and dog owners in contact with infected dogs. J Am Vet Med Assoc 238: 183-188.

62. Mesquita JR, Costantini VP, Cannon JL, Lin SC, Nascimento MS, et al. (2013) Presence of antibodies against genogroup VI norovirus in humans. Virol J 10: 176.

63. Susitaival P, Kirk J, Schenker MB (2001) Self-reported hand dermatitis in California veterinarians. Am J Contact Dermat 12: 103-108.

64. Susitaival P, Kirk JH, Schenker MB (2003) Atopic symptoms among California veterinarians. Am J Ind Med 44: 166-171.

65. Andersen CI, Von Essen SG, Smith LM, Spencer J, Jolie R, et al. (2004) Respiratory symptoms and airway obstruction in swine veterinarians: a persistent problem. Am J Ind Med 46: 386-392.

66. Valsecchi R, Leghissa P, Cortinovis R (2003) Occupational contact dermatitis and contact urticaria in veterinarians. Contact Dermatitis 49: 167-168.

67. Samadi S, Wouters IM, Heederik DJ (2013) A review of bio-aerosol exposures and associated health effects in veterinary practice. Ann Agric Environ Med 20: 206-221

68. Moghtaderi M, Farjadian S, Abbaszadeh Hasiri M (2014) Animal allergen sensitization in veterinarians and laboratory animal workers. Occup Med (Lond) 64: 516-520.

69. Gray GC, Ferguson DD, Lowther PE, Heil GL, Friary JA (2011) A national study of US bird banders for evidence of avian influenza virus infections. J Clin Virol 51: 132-135.

70. Myers KP, Olsen CW, Setterquist SF, Capuano AW, Donham KJ, et al. (2006) Are swine workers in the United States at increased risk of infection with zoonotic influenza virus? Clin Infect Dis 42: 14-20.

71. Zhou H, Cao Z, Tan L, Fu X, Lu G, et al. (2014) Avian-like A (H1N1) swine influenza virus antibodies among swine farm residents and pigs in southern China. Jpn J Infect Dis 67: 184-190.

72. Joosten M, Flahou B, Meyns T, Smet A, Arts J, et al. (2013) Case report: Helicobacter suis infection in a pig veterinarian. Helicobacter 18: 392-396.

73. Zelenik K, Avbersek J, Pate M, Lusicky M, Krt B, et al. (2014) Cutaneous listeriosis in a veterinarian with the evidence of zoonotic transmission--a case report. Zoonoses Public Health 61: 238-241.

74. Weller CB, Cadmus KJ, Ehrhart EJ, Powers BE, Pabilonia KL (2013) Detection and isolation of Influenza A virus subtype H1N1 from a small backyard swine herd in Colorado. J Vet Diagn Invest 25: 782-784.

75. Widdowson MA, Rockx B, Schepp R, van der Poel WH, Vinje J, et al. (2005) Detection of serum antibodies to bovine norovirus in veterinarians and the general population in the Netherlands. J Med Virol 76: $119-128$

76. Verkade E, van Benthem B, den Bergh MK, van Cleef B, van Rijen M, et al. (2013) Dynamics and determinants of Staphylococcus aureus carriage in livestock veterinarians: a prospective cohort study. Clin Infect Dis 57: e11-17.

77. Bosnjak E, Hvass AM, Villumsen S, Nielsen H (2010) Emerging evidence for Q fever in humans in Denmark: role of contact with dairy cattle. Clin Microbiol Infect 16: 1285-1288.

78. Bacci S, Villumsen S, Valentiner-Branth P, Smith B, Krogfelt KA, et al. (2012) Epidemiology and clinical features of human infection with Coxiella burnetii in Denmark during 2006-07. Zoonoses Public Health 59: 61-68.
79. Chaussade H, Rigaud E, Allix A, Carpentier A, Touzé A, et al. (2013) Hepatitis $\mathrm{E}$ virus seroprevalence and risk factors for individuals in working contact with animals. J Clin Virol 58: 504-508.

80. Moodley A, Nightingale EC, Stegger M, Nielsen SS, Skov RL, et al (2008) High risk for nasal carriage of methicillin-resistant Staphylococcus aureus among Danish veterinary practitioners. Scand J Work Env Hea 34: 151-157.

81. Baer R, Turnberg W, Yu D, Wohrle R (2010) Leptospirosis in a Small Animal Veterinarian: Reminder to follow Standardized Infection Control procedures. Zoonoses Public Hlth 57: 281-284.

82. Garcia-Graells C, Antoine J, Larsen J, Catry B, Skov R, et al. (2012) Livestock veterinarians at high risk of acquiring methicillin-resistant Staphylococcus aureus ST398. Epidemiol Infect 140: 383-389.

83. Burstiner LC, Faires M, Weese JS (2010) Methicillin-resistant Staphylococcus aureus colonization in personnel attending a veterinary surgery conference. Vet Surg 39: 150-157.

84. Rosenkranz KW, Rothenanger E, Brodard I, Collaud A, Overesch G, et al (2014) Nasal carriage of methicillin-resistant Staphylococcus aureus (MRSA) among Swiss veterinary health care providers: Detection of livestock-and healthcare-associated clones. Schweiz Arch Tierh 156: 217.

85. Cuny C, Nathaus R, Layer F, Strommenger B, Altmann D, et al (2009) Nasal Colonization of Humans with Methicillin-Resistant Staphylococcus aureus (MRSA) CC 398 with and without Exposure to Pigs. Plos One 4: e6800.

86. Sanhueza JM, Heuer C, Wilson PR, Benschop J, Collins-Emerson JM (2015) Prevalence and risk factors for Leptospira exposure in New Zealand veterinarians. Epidemiol Infect 143: 2116-2125.

87. Krumbholz A, Lange J, Dürrwald R, Hoyer H, Bengsch S, et al. (2010) Prevalence of antibodies to swine influenza viruses in humans with occupational exposure to pigs, Thuringia, Germany, 2008-2009. J Med Virol 82: 1617-1625.

88. Whitney EA, Massung RF, Candee AJ, Ailes EC, Myers LM, et al. (2009) Seroepidemiologic and occupational risk survey for Coxiella burnetii antibodies among US veterinarians. Clin Infect Dis 48: 550-557.

89. Leggat PA, Smith DR, Speare R (2009) Hand dermatitis among veterinarians from Queensland, Australia. Contact Dermatitis 60: 336-338.

90. Krakowiak A, Wiszniewska M, Krawczyk P, Szulc B, Wittczak T, et al. (2007) Risk factors associated with airway allergic diseases from exposure to laboratory animal allergens among veterinarians. Int Arch Occup Environ Health 80: 465-475.

91. Choudat D, Goehen M, Korobaeff M, Boulet A, Dewitte JD, et al. (1994) Respiratory symptoms and bronchial reactivity among pig and dairy farmers. Scand J Work Environ Health 20: 48-54.

92. Tauscher AE, Belsito DV (2002) Frequency and etiology of hand and forearm dermatoses among veterinarians. Am J Contact Dermat 13: 116-124.

93. Gielen K, Goossens A (2001) Occupational allergic contact dermatitis from drugs in healthcare workers. Contact Dermatitis 45: 273-279.

94. Hatch PH, Winefield HR, Christie BA, Lievaart JJ (2011) Workplace stress, mental health, and burnout of veterinarians in Australia. Aust Vet J 89: $460-468$

95. Shirangi A, Fritschi L, Holman CD, Morrison D (2013) Mental health in female veterinarians: effects of working hours and having children. Aust Vet J 91: 123-130.

96. Smith DR, Leggat PA, Speare R, Townley-Jones M (2009) Examining the dimensions and correlates of workplace stress among Australian veterinarians. J Occup Med Toxicol 4: 32.

97. Gardner DH, Hini D (2006) Work-related stress in the veterinary profession in New Zealand. N Z Vet J 54: 119-124.

98. Bartram DJ, Sinclair JM, Baldwin DS (2010) Interventions with potential to improve the mental health and wellbeing of UK veterinary surgeons. Vet Rec 166: 518-523. 
Page 11 of 12

99. Bartram DJ, Baldwin DS (2010) Veterinary surgeons and suicide: a structured review of possible influences on increased risk. Vet Rec 166 388-397.

100. Bartram DJ, Yadegarfar G, Baldwin DS (2009) Psychosocial working conditions and work-related stressors among UK veterinary surgeons. Occup Med (Lond) 59: 334-341.

101. Fritschi L, Morrison D, Shirangi A, Day L (2009) Psychological well-being of Australian veterinarians. Aust Vet J 87: 76-81.

102. Skipper GE, Williams JB (2012) Failure to acknowledge high suicide risk among veterinarians. J Vet Med Educ 39: 79-82.

103. Lawrence C (2009) Shock central: Veterinarians suicides. Corralonline.

104. Platt B, Hawton K, Simkin S, Mellanby RJ (2010) Systematic review of the prevalence of suicide in veterinary surgeons. Occup Med (Lond) 60: 436-446.

105. Platt B, Hawton K, Simkin S, Dean R, Mellanby RJ (2012) Suicidality in the veterinary profession: interview study of veterinarians with a history of suicidal ideation or behavior. Crisis 33: 280-289.

106. Kahler SC (2015) Moral stress the top trigger in veterinarians compassion fatigue: veterinary social worker suggests redefining veterinarians' ethical responsibility. J Am Vet Med Assoc 246: 16-18.

107. Aptel M, Aublet-Cuvelier A, Cnockaert JC (2002) Work-related musculoskeletal disorders of the upper limb. Joint Bone Spine 69: 546-555.

108. Schenker MB, Samuels SJ, Green RS, Wiggins P (1990) Adverse reproductive outcomes among female veterinarians. Am J Epidemiol 132: 96-106.

109. Steele LL, Wilkins JR 3rd (1996) Occupational Exposures and Risks of Spontaneous Abortion among Female Veterinarians. Int J Occup Environ Health 2: 26-36.

110. Lindbohm ML, Taskinen H (2000) Spontaneous abortions among veterinarians. Scand J Work Environ Health 26: 501-506.

111. Carpenter LM, Swerdlow AJ, Fear NT (1997) Mortality of doctors in different specialties: findings from a cohort of 20000 NHS hospital consultants. Occup Environ Med 54: 388-395.

112. Neil HA, Fairer JG, Coleman MP, Thurston A, Vessey MP (1987) Mortality among male anaesthetists in the United Kingdom, 1957-83. Br Med J (Clin Res Ed) 295: 360-362.

113. Wilkins JR, Bowman ME (1997) Needlestick injuries among female veterinarians: frequency, syringe contents and side-effects. Occup Med (Lond) 47: 451-457.

114. Beat VB, Morgan DP (1977) Evaluation of hazards involved in treating cattle with pour-on organophosphate insecticides. J Am Vet Med Assoc 170: 812-814.

115. Ames RG, Brown SK, Rosenberg J, Jackson RJ, Stratton JW, et al. (1989) Health symptoms and occupational exposure to flea control products among California pet handlers. Am Ind Hyg Assoc J 50: 466-472.

116. Glickman LT, Schofer FS, McKee LJ, Reif JS, Goldschmidt MH (1989) Epidemiologic study of insecticide exposures, obesity, and risk of bladder cancer in household dogs. J Toxicol Environ Health 28: 407-414.

117. Blair A, Cantor KP, Zahm SH (1998) Non-hodgkin's lymphoma and agricultural use of the insecticide lindane. Am J Ind Med 33: 82-87.

118. US Department of Health and Human Services (1998) Public Health Service, Centers for Disease Control, National Institute for Occupational Safety and Health NIOSH Alert: Preventing asthma in animal handlers.

119. WHO (2004) Laboratory Biosafety Manual. (3rd Edn) WHO, Geneva.

120. Lantos PM, Maggi RG, Ferguson B, Varkey J, Park LP, et al. (2014) Detection of Bartonella species in the blood of veterinarians and veterinary technicians: a newly recognized occupational hazard. Vector Borne Zoonotic Dis 14: 563-570.

121. Maggi RG, Mascarelli PE, Havenga LN, Naidoo V, Breitschwerdt EB (2013) Co-infection with Anaplasma platys, Bartonella henselae and Candidatus Mycoplasma haematoparvum in a veterinarian. Parasit Vectors 6: 103.
122. Lin JW, Chen CM, Chang CC (2011) Unknown fever and back pain caused by Bartonella henselae in a veterinarian after a needle puncture: a case report and literature review. Vector Borne Zoonotic Dis 11: 589-591.

123. Ergönül O, Zeller H, Kiliç S, Kutlu S, Kutlu M, et al. (2006) Zoonotic infections among veterinarians in Turkey: Crimean-Congo hemorrhagic fever and beyond. Int J Infect Dis 10: 465-469.

124. Reid AJ (2005) Brucellosis--a persistent occupational hazard in Ireland. Int J Occup Environ Health 11: 302-304.

125. Kutlu M, Ergonul O, Sayin-Kutlu S, Guven T, Ustun C, et al. (2014) Risk factors for occupational brucellosis among veterinary personnel in Turkey. Prev Vet Med 117: 52-58.

126. Shalmali, Panda AK, Chahota R (2012) Sero-prevalence of brucellosis in occupationally exposed human beings of Himachal Pradesh (India). J Commun Dis 44: 91-95.

127. Van den Brom R, Schimmer B, Schneeberger PM, Swart WA, van der Hoek W, et al. (2013) Seroepidemiological survey for Coxiella burnetii antibodies and associated risk factors in Dutch livestock veterinarians. PLoS One 8: e54021.

128. Thakur SD, Thapliyal DC (2002) Seroprevalence of brucellosis in man. J Commun Dis 34: 106-109.

129. Zemlickovs H, Fridrichovs M, Tyllovs K, Jakubs V, Machovs I (2009) Carriage of methicillin-resistant Staphylococcus aureus in veterinary personnel. Epidemiol Infect 137: 1233-1236.

130. O'Mahony R, Abbott Y, Leonard FC, Markey BK, Quinn PJ, et al. (2005) Methicillin-resistant Staphylococcus aureus (MRSA) isolated from animals and veterinary personnel in Ireland. Vet Microbiol 109: 285-296.

131. Vest KG, Clark LL (2014) Serosurvey and observational study of US Army Veterinary Corps officers for Q fever antibodies from 1989 to 2008. Zoonoses Public Health 61: 271-282.

132. Abe T, Yamaki K, Hayakawa T, Fukuda H, Ito Y, et al. (2001) A seroepidemiological study of the risks of $\mathrm{Q}$ fever infection in Japanese veterinarians. Eur J Epidemiol 17: 1029-1032.

133. Dorko E, Kalinova Z, Weissova T, Pilipcinec E (2008) Seroprevalence of antibodies to Coxiella burnetii among employees of the Veterinary University in Kosice, eastern Slovakia. Ann Agric Environ Med 15: 119-124.

134. de Rooij MM, Schimmer B, Versteeg B, Schneeberger P, Berends BR, et al. (2012) Risk factors of Coxiella burnetii (Q fever) seropositivity in veterinary medicine students. PLoS One 7: e32108.

135. Chang F, Syrjänen S, Wang L, Syrjänen K (1992) Infectious agents in the etiology of esophageal cancer. Gastroenterology 103: 1336-1348.

136. Wielders CC, Boerman AW, Schimmer B, van den Brom R, Notermans DW, et al. (2015) Persistent high IgG phase I antibody levels against Coxiella burnetii among veterinarians compared to patients previously diagnosed with acute $\mathrm{Q}$ fever after three years of follow-up. PLoS One 10: e0116937.

137. Fenga C, Gangemi S, De Luca A, Calimeri S, Lo Giudice D, et al. (2015) Seroprevalence and occupational risk survey for Coxiella burnetii among exposed workers in Sicily, Southern Italy. Int J Occup Med Environ Health 28: 901-907.

138. Shuhaiber S, Koren G, Boskovic R, Einarson TR, Soldin OP, et al. (2003) Seroprevalence of Toxoplasma gondii infection among veterinary staff in Ontario, Canada (2002): implications for teratogenic risk. BMC Infect Dis 3: 8 .

139. Rahman H, Murugkar HV, Kumar A, Islam M, Mukherjee S (2008) Seroprevalence of toxoplasmosis in a district of Assam, India. Indian J Public Health 52: 48-49.

140. Raso TF, Carrasco AO, Silva JC, Marvulo MF, Pinto AA (2010) Seroprevalence of antibodies to Chlamydophila psittaci in zoo workers in Brazil. Zoonoses Public Health 57: 411-416.

141. Rabozzi G, Bonizzi L, Crespi E, Somaruga C, Sokooti M, et al. (2012) Emerging zoonoses: the "one health approach". Saf Health Work 3: 77-83.

142. Milham S Jr (1971) Leukemia and multiple myeloma in farmers. Am J Epidemiol 94: 507-510. 
Citation: Bonini S, Buonacucina A, Selis L, Peli A, Mutti A, et al. (2016) Occupational Hazards in Veterinarians: An Updating. J Veterinar Sci

143. Pearce NE, Sheppard RA, Howard JK, Fraser J, Lilley BM (1986) Leukemia among New Zealand agricultural workers. A cancer registrybased study. Am J Epidemiol 124: 402-409.

144. Pearce NE, Smith AH, Howard JK, Sheppard RA, Giles HJ, et al. (1986) Case-control study of multiple myeloma and farming. Br J Cancer 54: 493-500.

145. Clavel J, Mandereau L, Cordier S, Le Goaster C, Hémon D, et al. (1995) Hairy cell leukaemia, occupation, and smoking. Br J Haematol 91: 154-161.

146. Johnson ES, Griswold CM (1996) Oncogenic retroviruses of cattle, chickens and turkeys: potential infectivity and oncogenicity for humans. Med Hypotheses 46: 354-356.

147. Travier N, Gridley G, Blair A, Dosemeci M, Boffetta P (2003) Cancer incidence among male Swedish veterinarians and other workers of the veterinary industry: a record-linkage study. Cancer Causes and Control 14: 587-593.

148. Seward JP (1999) Occupational allergy to animals. Occup Med 14: 285-304.

149. Chapman MD, Wood RA (2001) The role and remediation of animal allergens in allergic diseases. J Allergy Clin Immunol 107: S414-421.

150. Aoyama K, Ueda A, Manda F, Matsushita T, Ueda T, et al. (1992) Allergy to laboratory animals: an epidemiological study. Br J Ind Med 49: 41-47.

151. Heederick D, Venables KM, Malmberg P, Hollander A, Karlsson AS, et al (1999) Exposure-response relationship for work-related sensitization in workers exposed to rat urinary allergens: Results from a pooled study. J Allergy ClinImmunol 103: 678-684.

152. Kruize H, Post W, Heederik D, Martens B, Hollander A, et al. (1997) Respiratory allergy in laboratory animal workers: a retrospective cohort study using pre-employment screening data. Occup Environ Med 54: 830-835.

153. Fink-Gremmels J (1999) Mycotoxins: their implications for human and animal health. Vet Q 21: 115-120.

154. Schütze N, Lehmann I, Bönisch U, Simon JC, Polte T (2010) Exposure to mycotoxins increases the allergic immune response in a murine asthma model. Am J Respir Crit Care Med 181: 1188-1199.

155. Malik A, Ali S, Shahid M, Bhargava R (2014) Occupational exposure to Aspergillus and aflatoxins among food-grain workers in India. Int J Occup Environ Health 20: 189-193.

156. Bee D (2010) Suicide and mental wellbeing among vets. Vet Rec 166: 504.

157. Rollin BE (2011) Euthanasia, moral stress, and chronic illness in veterinary medicine. Vet Clin North Am Small Anim Pract 41: 651-659.

158. Lovell BL, Lee RT (2013) Burnout and health promotion in veterinary medicine. Can Vet J 54: 790-791.

159. Harling M, Strehmel P, Schablon A, Nienhaus A (2009) Psychosocial stress, demoralization and the consumption of tobacco, alcohol and medical drugs by veterinarians. J Occup Med Toxicol 4: 4.

160. Cooke MM, Gear AJ, Naidoo A, Collins DM (2002) Accidental Mycobacterium bovis infection in a veterinarian. N Z Vet J 50: 36-38. 